\title{
PEMANFAATAN MEDIA PEMBELAJARAN ICT DALAM MENINGKATKAN HASIL BELAJAR BAHASA INGGRIS PADA SISWA KELAS VIII-3 SMP NEGERI 9 TEBING TINGGI
}

\author{
Sri Mulyani \\ Surel: Srimul1370@gmail.com
}

\begin{abstract}
The purpose of this research was to develop learning english subject based on ICT method. This study used a qualitative descriptive analysis technique. The design, implementation, observation, and reflection stages of this classroom action research were carried out in two cycles. The participants in this study were 38 students from SMP Negeri 9 Tebing Tinggi class VIII3. The findings reveal that the use of ICT methods can improve student learning outcomes in English subjects which are determined by increasing student learning mastery, such as pre-cycle (60.52 percent), cycle I (78.94 percent), cycle II (89.47 percent). percent), and certification. classically successful (89.47 percent).
\end{abstract}

Keywords : ICT, English, Media.

\begin{abstract}
ABSTRAK
Penelitian ini bertujuan untuk meningkatkan hasil belajar siswa mata pelajaran Bahasa Inggris melalui metode ICT. Penelitian ini menggunakan teknik analisis dekriptif kualitatif. Tahap desain, implementasi, observasi, dan refleksi dari penelitian tindakan kelas ini dilakukan dalam dua siklus. Partisipan dalam penelitian ini adalah 38 siswa dari SMP Negeri 9 Tebing Tinggi kelas VIII-3. Temuan mengungkapkan bahwa penggunaan metode TIK dapat meningkatkan hasil belajar siswa dalam mata pelajaran bahasa Inggris yang ditentukan oleh peningkatan ketuntasan belajar siswa, seperti pra-siklus $(60,52$ persen), siklus I (78,94 persen), siklus II (89,47 persen), dan sertifikasi. berhasil secara klasikal (89,47 persen).
\end{abstract}

Kata Kunci : ICT, Bahasa Inggris, Media.

\section{PENDAHULUAN}

Berhasil atau gagalnya pencapaian tujuan pendidikan itu amat bergantung pada proses belajar yang dialami siswa baik berada di sekolah maupun di lingkungan rumah atau keluarganya sendiri (Syah, 2012 : 63). Belajar adalah aktivitas mental atau psikis yang berlangsung dalam interaksi aktif dengan lingkungan yang menghasilkan perubahanperubahan dalam pengetahuan. Belajar diartikan sebagai proses perubahan tingkah laku pada diri individu berkat adanya interaksi antara individu dan individu dengan lingkungannya (Usman, 2005:5). Perubahan perilaku itu merupakan perolehan yang menjadi hasil belajar. Bahasa Inggris merupakan alat komunikasi secara lisan dan tulis. Sedangkan berkomunikasi adalah memahami dan mengungkapkan informasi, pikiran, perasaan, dan mengembangkan ilmu pengetahuan, teknologi, dan budaya. Menurut Suyanto (2010 : 23), dalam pelajaran bahasa inggris ada empat kemampuan 
dasar yang harus dipelajari oleh semua siswa merupakan keterampilan menyimak (listening), berbicara (speaking), membaca (reading), dan menulis (writing) Keterampilan bahasa ini disajikan secara terpadu, seperti yang terjadi dalam kehidupan kita sehari-hari.

Perkembangan zaman dapat ditandai dengan kemajuan ilmu pengetahuan dan teknologi canggih (Roestiyah, 2008 : 153). Karena itu, metode pengajaran baru harus dikembangkan sebagai bagian dari proses belajar mengajar. Cara mengajar dengan menggunakan teknologi informasi dan komunikasi (ICT/ICT) adalah salah satunya. Guru harus terus berkembang atau paling tidak menyesuaikan taktik, pendekatan, dan teknologi pembelajarannya sebagai profesional. Jika tidak, para ahli ini akan melupakan pentingnya kehadiran dan pembelajaran.

Berdasarkan observasi yang dilakukan pada saat pra siklus, hasil belajar siswa kelas VIII-3 di SMP Negeri 9 Tebing Tinggi dinilai kurang memadai. Rendahnya nilai evaluasi ulangan harian pra siklus sebesar 67, dengan jumlah siswa yang lulus KKM 23 siswa, menunjukkan hal tersebut (60,52 persen). Nilai KKM yang dipilih adalah 70.Karena guru menggunakan media yang didalamnya terdapat unsur praktikum dan siswa dapat melihat materi yang disampaikan yaitu pembelajaran bahasa Inggris, selain itu berbagai metode ceramah, diskusi, tanya jawab dan tugas. berbasis ICT (Information and Communication Technology).

Fungsi utama media pembelajaran adalah sebagai alat pengajaran yang juga berdampak pada iklim, keadaan, dan lingkungan belajar yang diatur dan diciptakan oleh pengajar Arsyad, (2011:15). Penggunaan media dalam proses pembelajaran diduga dapat mendorong kegiatan belajar, meningkatkan motivasi, dan menghasilkan keinginan dan minat baru. Oleh karena itu, guru harus mampu memilih metode dan media pembelajaran yang tepat.

Usaha pemanfaatan visual sudah dilengkapi dengan audiovisual, seperti lahirnya media ICT (Information and Communication Technology) yang merupakan peralatan elektronik yang terdiri dari perangkat keras dan perangkat lunak serta segala kegiatan yang terkait dengan pemrosesan, manipulasi, pengelolaan, dan mentransfer atau pemindahan informasi antar media satu ke media lainya (Rusman, dkk., 2013 : 89).

Penggunaan teknologi dalam pendidikan dan pembelajaran $(e$ learning) dimaksudkan untuk memudahkan kegiatan pembelajaran. Dalam hal ini guur dituntut memiliki kemampuan menggunakan dan mempersiapkan materi pembelajaran dalam suatu sistem jaringan komputer yang dapat diakses oleh peserta didik. teknologi informasi dan komunikasi adalah segala bentuk teknologi yamg diterapkan untuk memproses dan mengirimkan dalam bentuk elektronik, setiap perangkat keras adalah komputer. Seiring dengan perkembangan zaman, dulunya komputer yang berbentuk besar, berat, dan tidak bisa dibawa kemanamana kini berinovasi menjadi barang 
simple, mudah untuk dibawa yang diberi nama laptop atau notebook (Warsita, 2008 : 135).

Teknologi komunikasi adalah segala sesuatu yang berkaitan dengan penggunaan alat bantu untuk memproses dan mentransfer data dari perangkat yang satu ke lainnya (Budiman, 2017 : 3). Teknologi informasi dan komunikasi dalam bahasa Inggris biasa disebut dengan istilah information and communication technology (ICT). Secara umum teknologi informasi dan komunikasi dapat diartikan sebagai semua teknologi yang berhubungan dengan pengambilan, pengumpulan, pengolahan,

penyimpanan,

penyebaran, dan penyajian informasi (Asmani, 2011: 99).

Pembelajaran berbasis ICT (Information and Communication Technology)/TIK adalah suatu sistem pembelajaran di mana dalam proses belajar mengajarnya disesuaikan dengan memanfaatkan teknologi informasi dan komunikasi. ICT (Information Communication and Technology) dapat digunakan untuk memudahkan kerja sama antara pendidik dengan peserta didik yang letaknya berjauhan secara fisik. Dahulu, seseorang harus berjalan jauh untuk menemui seorang pakar guna mendiskusikan sebuah masalah. Saat ini hal itu dapat dilakukan dari rumah dengan mengirimkan e-mail. Makalah dan penelitian dapat dilakukan dengan saling tukar menukar data melalui internet, e-mail, ataupun dengan menggunakan mekanisme file sharing.
Menurut Warsita (2008 : 150). Learning through computers and the internet, yaitu mengintegrasikan pengembangan keterampilanketerampilan berbasis ICT (Information Communication and Technology) dengan aplikasi-aplikasi dalam kurikulum. Misalnya di perguruan tinggi, sebagai contoh mahasiswa melakukan riset online, menggunakan spreadsheet dan program database untuk membantu mengorganisasikan dan menganalisis data yang telah dikumpulkan atau menggunakan word processing untuk menyusun laporan penelitian. Oleh karena itu, komputer dapat juga digunakan sebagai alat bantu untuk melakukan proses tertentu, misalnya perhitungan atau kalkulasi dan penyimpanan data serta pemprosesan kata dan data (word and data processing).

Dengan menggunakan ICT tentu saja diharapkan pelajar mampu menumbuhkan kreativitasnya dengan maksimal yang terdapat didalam diri mereka. Dengan demikian, tujuan ICT akan sejalan dengan tujuan pendidikan itu sendiri ketika digunakan dalam pembelajaran. Penggunaan ICT tidak menjadi penghambat dalam pembelajaran, namun akan memberi manfaat lebih dalam pembelajaran (Nurdyansyah dan Andiek Widodo, 2017 : 99). Strategi pembelajaran dengan ICT berarti mengintegrasikan strategi pembelajaran dalam proses pembelajaran dengan media ICT untuk mengemas pembelajaran lebih menarik, menyenangkan, efektif dan 
efesien bagi guru dan peserta didik. Dalam hal ini, media ICT menjadi sarana pendukung pembelajaran agar proses pembelajaran semakin interaktif.

Berdasarkan permasalahan tersebut merasa tertarik untuk melakukan penelitian tentang bagaimanakah implementasi pembelajaran berbasis ICT (Information and Communication Technology) pada mata pelajaran Bahasa Inggris di kelas VIII-3 SMP Negeri 9 Tebing Tinggi dalam menciptakan suasana pembelajaran yang kondusif, menyenangkan bagi peserta didikserta merangsang siswa untuk aktif dan menimbulkan semangat belajar sehingga tujuan pembelajaran. Pembelajaran dengan ICT memberi kesempatan kepada peserta didik berpartisipasi lebih aktif untuk meluangkan ide-ide atau masalah-masalah yang dihadapi melalui pengajuan soal yang nantinya akan ditukarkan dengan kelompok lain untuk dijawab yang nantinya akan dibahas bersama.

Penelitian ini bertujuan untuk memanfaatkan media pembelajaran ICT pada mata kuliah Bahasa Inggris untuk meningkatkan aktivitas dan hasil belajar siswa kelas VIII-3 di SMP Negeri 9 Tebing Tinggi Tahun Pelajaran 2019/2020.

\section{METODE PENELITIAN}

Metode penelitian adalah cara yang digunakan oleh peneliti dalam mengumpulkan data penelitiannya (Arikunto, 2002 : 136). Metode yang digunakan dalam penelitian ini adalah penelitian tindakan kelas. Penelitian tindakan kelas dalam bahasa inggris disebut dengan istilah classroom action research (Arikunto, $2007: 2$ ). Peneliti berkolaborasi dengan guru dalam merencanakan, mengidentifikasi, mengobservasi, dan melaksanakan tindakan yang telah dirancang. Rancangan penelitian yang digunakan adalah Penelitian Tindakan Kelas sistem spiral dengan model Hopkins.

Penelitian ini berlangsung pada bulan Januari tahun ajaran 2019/2020, selama semester genap. Sebanyak 38 siswa kelas VIII-3 SMP Negeri 9 Tebing Tinggi mengikuti pembelajaran, terdiri dari 18 putra dan 20 putri. Siswa dan rekan dipekerjakan sebagai sumber data. Data yang diperoleh dalam penelitian tindakan kelas dapat bersifat kuantitatif atau kualitatif. Membandingkan skor tes kondisi awal, skor tes setelah siklus I dan II yaitu skor dari hasil ulangan harian siswa kelas VIII-3 SMP Negeri 9 Tebing Tinggi pada siklus I dan II, data kuantitatif berupa skor dianalisis dengan menggunakan analisis deskriptif komparatif.

Penelitian ini dilaksanakan sesuai dengan rancangan penelitian model Hopkins yang diawali dengan tindakan pendahuluan kemudian dilanjutkan perencanaan, tindakan, pengamatan, dan refleksi. Penelitian dilakukan sebanyak 2 siklus. Hasil evaluasi pada siklus I masih belum tuntas, sehingga dilakukan perbaikan pada siklus II. Refleksi siklus I dilakukan untuk menentukan langkahlangkah perbaikan pada siklus II sebagai berikut: 


\section{Perencanaan}

Peneliti mempersiapkan pelaksanaan PTK dengan membuat skenario pembelajaran, membuat media, dan membuat perangkat pembelajaran tambahan, antara lain. Rencana pembelajaran, lembar observasi, lembar kerja, dan pertanyaan tes hanyalah beberapa contoh. Selain mempersiapkan itemitem tersebut, peneliti juga harus menetapkan indikator pencapaian dalam pemanfaatan pembelajaran ICT agar penelitian ini dapat terlaksana dengan tujuan yang jelas.

\section{Pelaksanaan}

Tindakan dalam PTK mengacu pada pelaksanaan tugas atau pembelajaran yang diarahkan oleh rencana pelaksanaan pembelajaran yang dibuat dengan menggunakan media pembelajaran ICT. Sebagai pengantar, guru menyajikan materi pokok, dan siswa memperhatikan penjelasan guru. Siswa mendengarkan penjelasan guru sebelum mengerjakan LKS dalam kegiatan diskusi kelompok untuk lebih mendalami konten. Pada tanggal 15 Januari 2020, Siklus I telah selesai. Pada tanggal 22 Januari 2020, Siklus II telah selesai. Selama kegiatan pembelajaran, pengamat lain membantu pengajar sebagai peneliti dalam melakukan pengamatan dan pendokumentasian kegiatan. Selain itu, peneliti bertindak sebagai fasilitator, motivator, dan sekaligus pengamat.

\section{Observasi/Pengamatan}

Observasi dilakukan oleh sejumlah orang, antara lain guru, peneliti, dan rekan kerja. Observasi dilakukan selama proses pembelajaran dengan mengacu pada lembar observasi peneliti. Aktivitas siswa selama proses pembelajaran harus diamati oleh pengamat, dan proses pembelajaran harus dilakukan sesuai dengan rencana pelaksanaan pembelajaran. Selain itu, hasil observasi dianalisis untuk menilai aktivitas siswa, guru, dan pembelajaran tentunya.

\section{Refleksi}

Berdasarkan lembar observasi yang diisi oleh pengamat, peneliti menganalisis, melihat, dan mempertimbangkan hasil atau akibat dari tindakan yang dilakukan. Tahap refleksi meliputi menganalisis, memahami, dan menarik kesimpulan berdasarkan temuan pengamatan setiap siklus. Mengidentifikasi keuntungan dan kerugian dari berbagai strategi peningkatan pembelajaran. Sebagai acuan, hasil analisis data yang dilakukan pada tahap ini akan digunakan untuk mengidentifikasi kekuatan dan kelemahan dalam membuat dan melaksanakan kegiatan.

Dalam penelitian ini, pedoman observasi, ujian hasil belajar, dan wawancara digunakan sebagai instrumen. Observasi digunakan untuk memperoleh data tentang kegiatan pembelajaran dan hambatan yang dihadapi selama proses pembelajaran (lembar observasi 
terlampir). Aktivitas verbal, aktivitas metrik, dan aktivitas emosional semuanya akan diamati. Data observasi dan data wawancara dengan pernyataan sebagai bentuk data dievaluasi menggunakan teknik analisis statistik deskriptif. Metode pengumpulan data tertulis dan observasional digunakan dalam penelitian ini. Penelitian ini dianggap berhasil jika siswa mencapai nilai ketuntasan klasikal minimal 85 persen dari jumlah keseluruhan siswa dengan menggunakan rumus:

Persentase Ketuntasan klasikal $=$

Jumlah siswa yang tuntas $\quad$ X $100 \%$

Jumlah siswa yang mengikuti tes

\section{HASIL PENELITIAN DAN PEMBAHASAN}

Pembelajaran dengan memanfaatkan teknologi informasi yang ada diharapkan supaya siswa dapat memahami, menghafal, dan mengerti. Dalam menggunakan teknologi informasi dan komunikasi yang ada yang pertama kali dilakukan adalah membuat rencana pembelajaran, sebelum mengajar persiapan yang dilakukan guru Bahasa Inggris adalah mempersiapkan RPP, dalam konteks ini program benar-benar dirancang guru benar-benar rencana pribadi tentang apa yang dikerjakannya bersama siswa kemudian mempersiapkan pokok bahasan atau materi pembelajaran tentang apa yang dibahas kemudian mempersiapkan media pembelajaran

dengan teknologi informasi yang sesuai dan tepat guna.
Peneliti melaksanakan prasiklus yang bertujuan untuk mengetahui kemampuan awal siswa pada materi penarikan kesimpulan logika matematika dan untuk dijadikan alat dalam pembentukan kelompok yang bersifat heterogen. Dari hasil analisis tes awal tersebut peneliti memeriksa bahwa dari 38 orang siswa yang mengikuti tes tersebut, hanya terdapat 24 orang siswa yang dapat menyelesaikan soal dengan benar. Hal ini menunjukkan bahwa pemahaman siswa mengenai materi yang diberikan masih kurang sehingga tidak mencapai ketuntasan klasikal yang telah ditetapkan. Temuan penelitian tindakan kelas menunjukkan bahwa pengamatan terhadap aktivitas guru dan siswa melalui penggunaan media pembelajaran TIK berikut dilakukan oleh mitra kerjasama dan peneliti sebagai berikut:

Tabel 1. Peningkatan Hasil Belajar Siswa Pra Siklus, Siklus I dan II

\begin{tabular}{c|c|c|c}
\hline \multicolumn{2}{c|}{ Peningkatan Hasil Belajar } & \multirow{2}{*}{ Keterangan } \\
\cline { 1 - 2 } $\begin{array}{c}\text { Pra } \\
\text { Siklus }\end{array}$ & $\begin{array}{c}\text { Siklus } \\
\text { I }\end{array}$ & $\begin{array}{c}\text { Siklus } \\
\text { II }\end{array}$ & \\
\hline 23 & 30 & 34 & Siswa Lulus \\
\hline 60,52 & 78,94 & 89,47 & $\begin{array}{c}\text { Persentase } \\
\text { Ketuntasan } \\
\text { Belajar (\%) }\end{array}$ \\
\hline 72 & 78,5 & 85 & $\begin{array}{c}\text { Aktivitas } \\
\text { Belajar (\%) }\end{array}$ \\
\hline $\begin{array}{c}\text { Tidak } \\
\text { Tuntas }\end{array}$ & $\begin{array}{c}\text { Tidak } \\
\text { Tuntas }\end{array}$ & Tuntas & $\begin{array}{c}\text { Ketuntasan } \\
\text { Secara } \\
\text { Klasikal }\end{array}$ \\
\hline
\end{tabular}

Berdasarkan pengamatan peneliti dari kegiatan pra siklus, proporsi ketuntasan belajar klasikal meningkat pada siklus I dan II 
sehingga terjadi peningkatan hasil dan aktivitas belajar siswa. Pada siklus I persentase siswa yang belajar dengan cermat pada ulangannya adalah 78,94 persen, naik 18,42 persen dari pra siklus. Pada siklus I terdapat 30 siswa yang belajar secara klasikal ekstensif, dengan aktivitas belajar 78,5 persen. Saat melaksanakan proses pembelajaran menggunakan media pembelajaran ICT ini guru bertindak sebagai motivator dan fasilitator. Hal tersebut berarti bahwa guru tidak menerangkan atau memberikan seluruh materi kepada peserta didik, tetapi hanya membantu peserta didik yang mengalami kesulitan dalam memahami materi pembelajaran, dan menyediakan peralatan yang diperlukan dan memberikan instruksi terkait dengan proses pembelajarannya.

Setelah para peserta didik dibagi ke dalam kelompoknya, maka instruksi dari guru adalah peserta didik diminta untuk mempelajari suatu materi dan peserta didik diberi kebebasan untuk mencari literatur dari mana saja serta sebanyakbanyaknya yang mereka mampu temukan. Jadi peserta didik diminta untuk mempelajari suatu materi baru secara mandiri tanpa guru menerangkan terlebih dahulu di depan kelas seperti pada metode pembelajaran konvensional, di mana pembelajaran terpusat pada guru. Hal tersebut mau tidak mau memacu peserta didik untuk berusaha mencari sumber/literatur sendiri apabila mereka ingin dapat memahami materi.

\section{Pembahasan}

Pada siklus I hasil belajar masih dalam kategori kurang baik dan indeks peningkatan hasil belajar masih dalam kategori tidak tuntas (85 persen), maka ketuntasan belajar yang terjadi pada siklus I belum optimal. Namun, meskipun hasilnya tidak sesuai dengan indikator keberhasilan, terjadi peningkatan hasil belajar siswa dari pra siklus ke siklus I. Hal ini menunjukkan bahwa siswa lebih bersemangat belajar ketika media pembelajaran ICT digunakan lebih bersemangat dalam belajar karena siswa cenderung lebih senang jika memperoleh materi tidak hanya mendengarkan guru namun dapat melihat bahkan mendengar dari gambar, video ataupun power point yang ditampilkan.

Beberapa siswa yang belun tuntas belajar karena tidak serius dan tidak fokus sehingga Suka bermain sendiri dan sulit dikendalikan. Lebih lanjut, menurut mitra kerjasama, guru masih menggunakan bahasa yang sulit dipahami dan dipahami siswa saat memberikan arahan atau penjelasan, sehingga membuat siswa bingung. karena tidak terbiasa dengan Bahasa Inggris. Alangkah baiknya pada siklus II setelah kegiatan pembelajaran ini dapat dilakukan beberapa tindakan konkret dalam rangka mewujudkan meningkatkan kualitas pembelajaran dengan latihan conversation kepada teman sekelompoknya.

Tingkat ketuntasan belajar meningkat menjadi 89,47 persen pada siklus II, dengan 34 siswa dari 38 
siswa menyelesaikan studinya. Temuan tersebut menunjukkan bahwa mereka telah tuntas belajar pada siklus II dan telah memenuhi kriteria persentase ketuntasan yang diinginkan yaitu > 85 persen. Persentase siswa yang mengikuti kegiatan mencapai 85 persen. Hal ini sesuai dengan hakikat belajar, yang biasanya berupa perubahan tingkah laku atau penampilan yang disertai dengan serangkaian tindakan. Membaca, mengamati, mendengarkan, meniru, dan metode lainnya adalah contohnya. Selanjutnya, belajar akan meningkat jika individu mengalami atau melakukannya, bukan hanya mendengar tentang hal itu.

Dalam menciptakan suasana pembelajaran yang kondusif dan efisien, di era globalisasi ini guru harus mampu dalam mengaplikasikan teknologi pembelajaran yang berbasis internet (e-learning) yang dapat mempermudah pemahaman dan meningkatkan motivasi belajar peserta didik. Terlebih dalam pelajaran Bahasa Inggris yang sering dianggap remeh oleh pesrta didik, mereka menganggap pelajaran ini bukan pelajaran yang penting sehingga kurang diminati. Dengan penerapan media pembelajaran ICT dapat meningkatkan penguasaan materi siswa untuk mata pelajaran Bahasa Inggris. Meskipun beberapa anak muda terus melakukan kesalahan, secara keseluruhan, dapat dikatakan bahwa jumlah kesalahan terus meningkat. Melalui penggunaan ICT di dalam kelas, guru juga memberikan contoh-contoh konkrit yang bisa siswa temukandalam kehidupan sehari-hari untuk menarik perhatian murid. Selain itu, muridmurid diajak terlibat dan beraktifitas langsung dalam kegiatan pembuatan daftar informasi dan penggalian data baik di kelas maupun di

lapangan.

Hal ini sejalan dengan pendapat Nurdyansyah dan Andiek Widodo (2017 : 99) bahwa ICT menumbuhkan kreativitasnya dengan maksimal yang terdapat didalam diri mereka. Dengan demikian, tujuan ICT akan sejalan dengan tujuan pendidikan itu sendiri ketika digunakan dalam pembelajaran. Penggunaan ICT tidak menjadi penghambat dalam pembelajaran, namun akan memberi manfaat lebih dalam pembelajaran. Maka dari itu penerapan media pembelajara ICT, siswa didorong untuk berpikir sendiri, menganalisis sendiri, sehingga dapat menemukan konsep, prinsip, ataupun prosedur berdasarkan bahan ajar yang telah disediakan guru.

Hal ini ditunjukkan dengan adanya peningkatan penguasaan materi dan hasil belajar siswa sebagai akibat dari hasil yang dikumpulkan dari setiap siklus proses pembelajaran yang optimal. Hasilnya, dapat disimpulkan bahwa proses pembelajaran yang melibatkan penggunaan TIK sesuai dengan topik bahasa Inggris. Maka penelitian Tindakan Kelas (PTK) ini dapat dikatakan berhasil. karena hasil peningkatan proses pembelajaran yang optimal. 


\section{SIMPULAN}

Pelaksanaan pembelajaran ICT berhasil meningkatkan hasil belajar peserta didik. Dari hasil temuan penelitian pada siswa kelas VIII-3 SMP Negeri 9 Tebing Tinggi tahun pelajaran 2019/2020 diperoleh ICT dapat meningkatkan hasil belajar dan aktivitas siswa. Hal ini terlihat pada peningkatan persentase ketuntasan belajar siswa pada siklus I $(78,94 \%)$ dan siklus II $(89,47 \%)$. Dari segi aktivitas belajar siswa, 78,5 persen pada siklus I meningkat menjadi 85 persen pada siklus II.

\section{DAFTAR RUJUKAN}

Asmani, Jamal Ma'mur. 2011. Buku

Panduan

Internalisasi

Pendidikan Karakter di

Sekolah. Jogjakarta: Diva Press.

Arikunto, Suharsimi. 2002. Prosedur Penelitian. Jakarta: Rineka Cipta.

Arikunto, Suharsimi. 2007. Penelitian

Tindakan Kelas. Jakarta: Bumi Aksara.

Arsyad, Azhar. 2011. Media Pembelajaran. Jakarta: Raja Grafindo Persada.

Budiman, Haris. 2017. Peran Teknologi Informasi dan Komunikasi Dalam Pendidikan. Jurnal Pendidikan Islam, Vol. 8: (1), Halm. 3143.

Nurdyansyah dan Andiek Widodo. 2017. Manajemen Sekolah Berbasis ICT. Sidoarjo: Nizamia Learning Center.
Roestiyah N.K. 2008. Strategi Belajar Mengajar. Jakarta: Rineka Cipta.

Rusman, Deni Kurniawan, dan Cepi Riyana. 2013. Pembelajaran Berbasis Teknologi Informasi dan Komunikasi:

Mengembangkan

Profesionalitas Guru. Jakarta: Raja Grafindo Persada

Suyanto, Kasihani K. E. 2010. English For Young Learning. Jakarta: Bumi Aksara.

Syah, Muhibbin. 2012. Psikologi Belajar. Jakarta: Raja Grafindo Persada

Usman, Moh.Uzer 2005. Menjadi Guru Profesional. Bandung: Remaja Rosdakarya.

Warsita, Bambang. 2008. Teknologi Pembelajaran: Landasan dan Aplikasinya. Jakarta: Rineka Cipta. 